\title{
The Unknown and the Unknowable In Law
}

\section{Helen Silving*}

THE COURSE of the law is influenced by various types of philosophy. Of course, the influence of jurisprudence, the philosophy whose specific subject matter is law, is well recognized. Every lawyer knows that jurisprudential opinions-conceptions of the nature, meaning and operation of law-have at all times found expression in legislative acts, judicial and administrative decisions. Social and economic philosophies are incontestibly other important factors in shaping the law.

Beyond these, there is a type of philosophy active in law which has hitherto received only scant theoretical consideration. ${ }^{1}$ Law is concerned with phenomena of the outside world other than legal, social and economic phenomena, and inquires into their nature and its own ability to take cognizance of them. To be sure, the ultimate determination of the nature of physical phenomena in law is specifically legal, and at law things are what the law holds them to be, anything science or philosophy may say to the contrary notwithstanding. This legal determination, however, may in turn be influenced by extralegal considerations. Thus, ideas of "natural" philosophy, i.e., conceptions of the nature of reality, and theories of knowledge, may determine the law's attitude toward legally relevant objects of observation. The law may assume a particular philosophy of nature. This type of legal philosophy may be called the "natural philosophy of the law".2

An inquiry into its elements may prove to be of practical value. If various legal rules, or even entire fields of law, can be, at least partially, rationalized on the ground of such philosophy, then these

*Member New York Bar; Dr. Jur., Dr. rer. pol., University of Vienna; LL.B., Columbia University.

1. The nuost comprehensive discussion is offered by Sokolowski. DIE PHILOSOPHIE ar Privatrecht, SAchbegriff UNd Koerper IN DER Krassaschin JuRISPRUdeñ UND DER Modernen Gesetzgebung (1902).

2 The problem discussed here is not peculiar to any particular system of law. The legal rules cited in this paper are used for the purpose of illustrating general trends of legal development at large, and they are chosen from various systems of law, the AngloAmerican as well as continental European. 
rules have a common denominator which constitutes a basis of comparison between them. Ours is a relative justice. This means that in similar situations similar rules are applicable. It further means that if a given proposition is recognized as ground of decision in one situation, it ought to be given consideration also in another situation in which it is equally valid. It is the purpose of this paper to point out a possible relationship between fields of law which are generally treated as unrelated to each other. They are the field of the law of mistake, that of freedom of religion, and the somewhat inchoate sphere of freedom of science. It is submitted that their common denominator is an underlying philosophy of nature or particular theories of such philosophy. It is further submitted that, although involved in each of these fields, natural philosophy or rather its propositions, as prevailing at any given time, have not been given equal consideration in such fields.

The very starting point of this investigation, however, is highly controversial. Are legal rules concerning nature and its cognition ever based on particular natural philosophies? Natural philosophy deals with two fundamental questions: the ontological question, What is the nature or essence of things?, and the epistemological one, Can we, how and to what extent can we acquire knowledge of things? The law treats these two categories of questions in two fields, the substantive law of mistake and the procedural law of evidence. The conventional strict separation of these two fields of law has given rise to a misconception of the place which the entire field of natural philosophy occupies within the law. It would seen that an important part of natural philosophy is here omitted, i.e., the problem of reality. The touchstone of a philosophical theory of reality is the interpretation of error. Philosophy, indeed, cannot arrive at a theory of reality independently from a theory of error. The law, on the other hand, seemingly proceeds from the givenness of reality and derives its theory of mistake from it. Mistake is a priori defined in law as a false conception of reality, ${ }^{3}$ and reality is said to be what is considered as such in prac-

3 "It is uncontested that the concept of error must be derived from the concept of truth; and since we are proceeding entirely on the ground of experience, a deduction from the empirical concept of truth of particular sciences or from the general concept of epistemological empirical realism is sufficient for our purposes. Having thus defined the nature of positive error, it is comparable to the definition of ignorance. . . "Lerch, Zur Lelire vom Recitsirrtum in Strafrecht (1928) 38 ABHANDLUNGEM zOM SCHWEIZERISCHEN RECHT (New Series) 4, 5. The first premise of this argument is misleading. The concept of error is not simply derived from that of truth, unless what the author has im mind are ultimate results rather than nethods. How little common ground there 
tical everyday life. Kuhlenbeck's application to law of the arguments that there is no such thing as a correct conception of reality, and that it is just as difficult to describe the true nature of mistake as it is to explain the concept of truth, ${ }^{4}$ has thus been challenged as having no validity, the law being satisfied with what is commonly accepted as existent or real. ${ }^{5}$ The assumed practical "reality" of the law of mistake is, in turn, believed to be applicable to all the branches of law. Such a conception of reality leaves no room for a philosophy of nature. Once, however, the relativity and interdependence of the substantive law of mistake and the procedural law of evidence is demonstrated, and the "reality" of the former shown to be but the product of a process, as regulated by the latter, the substantive givenness at law of reality is shown not to coincide necessarily with the practical givenness of things and facts, as conceived in everyday life. "Reality", within the meaning of the law of mistake, being thus divested of its character of givenness, the entire problem of what we have chosen to call the "natural philosophy of the law" is opened.

Natural philosophy is also involved, though in modern times only indirectly, in the attitude of law toward particular conceptions of reality, such as the religious and scientific. The law's promotion of such conceptions, its tolerance or intolerance of them, its solution of possible conflicts between science and religion or between the scientific and religious approach, to some extent itself expresses a theory of reality and of knowledge.

Theories of reality and of knowledge, to be sure, are most clearly expressed in the law of evidence. The problem of reality within the meaning of the law of evidence has been touched upon elsewhere. ${ }^{6}$ As a separate problen, it will be onntted here. It should not be overlooked, however, that "reality" as assumed in substantive law originates in the process of evidence and bears the mark of its origin.

is between what the author calls "empirical" reality and legal reality, and hence between "empirical" and legal mistake, may be seen from the fact that at law, the lack of any conception of reality is included within the wider sense of mistake. But psychologically and logically, lack of knowledge, total absence of any proposition, is, of course, something entirely different from false knowledge or propositions contradictory to truth.

4 Kuhlenbeck, Von den Pandekten zum Buergeritchen Gesetzbuch (1898) I TEII 403 et seq.

5 Roeder, Schuld und Irrtum in Justiz- und Verwaltungsstrafrecitt (1938) 387 STRAFRECHTLICEE ABHANDLUNGEN 71, note 90.

'See Silving, Law and Fact in the Light of the Pure Theory of Law in INTERPREtations of Modern Legal Philosophies (1947) 642. 


\section{THE LAW OF REALITY AND MISTAKE}

Already the Roman law of mistake has given rise to the question whether legal rules concerming objects of the outside world are based on particular natural philosophies. This law proceeded from the assumption that there are certain inherent qualities of things which determine their essence and identity, independently of the relative importance attributed to such qualities by the parties. Thus, Ulpian's classical theory of the oút $\alpha^{\mathrm{T}}$ held a sale to be valid when winevinegar was delivered instead of wine, but to be invalid when ore was sold as gold, lead as silver, vinegar produced froin a concoction other than wine as wine. In the first instance, it was believed, the substance is the same, eadem oúri $\alpha$ est, in the other instances it is not. This legal theory gave rise to a vigorous controversy among jurists. Soine of them hold it to be a creature of the "substance-theory" of the Stoics who saw the essence and origin of things in the substance of which they are made rather than in their outward form. ${ }^{8}$ According to this. theory, wine and winevinegar consist of the same substance, while ore and gold, lead and silver, vinegar not produced from wine and wine do not. Ehrlich, on the other hand, denies any relationship between the legal and the philosophical theory and clamis that the former is but a product of the usages of Roman wine merchants. ${ }^{9}$ He fails to explain, lowever, what was the background and rationale of such usages.

Whatever the origin of the Roman law of mistake, the subsequent legal development is strangely similar to changes observable in the history of natural philosophy. In that philosophy, in the course of time, the two questions mentioned above, the ontological and the epistemological, became interrelated, as the "nature" of things becaine to some extent a function of cognition, and the subject of cognition won predominance at the expense of its object. ${ }^{10}$ As was the case

7 L. 9. 2 DIG. DE CONTR. EMPT. 18. I (Ulpianus libro vicensimo octavo ad Sabinum): "Inde quaeritur, si in ipso corpore non erratur, sed in substantia error sit, ut puta si acetum pro vino veneat, aes pro auro, vel plumbum pro argento, vel quid aliud argento simile, an emptio et venditio sit. Marcellus scripsit libro sexto Digestorum emptionem esse et venditionem, quia in corpus consensum est, etsi in materia non sit erratum. Ego in vino quidem consentio, quia eadem prope oủoia est, si modo vinum acuit; ceterum si vinum non acuit, sed ab initio acetum fuit, ut embamma, aliud pro alio venisse videtur. In ceteris autem nullam esse venditionem puto, quotiens in materia erratur."

8 See particularly Sokolowski, op. cit. supra note 1, at 238 et seq.

9 Ehrlicl, Ulpian's 'OY MODERNO E di STORIA DET DIRITTO 732.

10 Even linguistically the shift found expression, in that, as Mauthner (2 WOERTERBUCH DER PHILOSOPHIE 442, "Objektiv") points out, the meaning of the concept of the 
in philosophy, so in law, the emphasis was transferred from the object to the perceiving subject. The essence of a thing ceased to be regarded as inherent in the thing itself and became "something which both [parties] must necessarily have accepted in their minds as an essential and integral element of the subject-matter."11 The stress on the subject rather than on the object found its most accurate expression in the meeting-of-the-minds theory of contract which requires for the formation of a contract a concurrence of subjective conceptions or wills based on such conceptions.

In criminal law also the attention originally directed to the object of legal protection was later diverted to the personality of the criminal actor. Not only his ethical but also his cognitive relation to the object caine to the foreground. Legal protection was indeed made dependent on a specific subjective cognitive relation of the actor to the object. Thus, a defendant who intended to kill $A$ but mistaking $B$ for him, shot at the latter, was occasionally treated differently from a defendant who, being fully aware of the respective identities of $A$ and $B$, and intentionally aiming at $A$, missed the mark and accidentally harmed $B .{ }^{12}$ It was pointed out that the error in obiecto is a purely subjective intellectual problem, as compared with the aber. ratio ictus which is something physical and hence objective. ${ }^{13}$ The identity problem as present in the mind of the defendant was considered decisive, and thus the cognitive subjective element stressed at the expense of the similarity of both the moral reprehensiveness of intent and the results of the criminal act. Attempts at justifying a similarity of legal treatment in the two instances indeed ventured to

"subject" of cognition and that of its "object" were reversed, so that we now refer to the "subject" when intending to denote what the Middle Ages described as the "object" and vice versa. In law this shift is noticeable in the first instance within the law of mistake itself. Beyond that, it finds expression in a change of emphasis in the relation of the substantive law of mistake to the procedural law of evidence, a change already mentioned in the present paper. Thirdly, it is reflected within the himits of the law of evidence.

11 Bell v. Lever Brothers, Ld. [1932] A. C. 161, 235.

12 So far as American law is concerned, see cases cited in MILLER, HaNdBook or Crominal Law (1934) 65, note 67. A differentiation between error and aberratio is made in Italian legal literature, for instance, by ARENA, L'AbERRATIo Ictus (1909) 4. In contrast to the Italian theory which applies the distinction also in the case where the person other than the intended one was killed, the American law limits the differential treatment to the case of wounding a person other tiran one intended to be hilled. Where death occurs the doctrine of "transfer of intent" applies. It is then said that "the intention follows the bullet". State v. Batson (1936) 339 Mo. 298, 96 S.W. (2d) 384. See also Ragar v. State (1930) 180 Ark. 1131, 1135, 1136, 24 S.W. (2d) 334, 335.

13 Hackel, Error in obiecto und aberratio ictus in italienischen Strafrecht (1935) StrafrechtLICHE ABHANDLUNGEN 5, 6. 
reduce them to the same subjectivistic formula. The aberratio, like error, was said to disclose a false conception of reality on the part of the actor; only in the former, that false conception consisted in a wrong appreciation of causality rather than in an incorrect identification of a person. Elements of this orientation to the subject and subjective cognition rather than to the object and its protection may be said to be contained also in the German theory of aberratio. This theory asserts that in the case of aberratio the crimmal act consists of two component parts, attempt plus negligent action. ${ }^{14}$ Thus a connection is upheld between the intended, subjectively specified, and the actually harmed object.

The law itself, when considered in its existential rather than in its normative character, is an object of cognition like any other phenomenon of the outside world. ${ }^{15}$ As such it may be the object of error, just as, on the other hand, each mistake of fact may be regarded as an error of law, in that it is error concerning facts established as true in a legal procedure. The philosophical metamorphosis discussed above is noticeable also in the technical sphere known as that of "error of law". Its scope, however, is somewhat different here. Whereas in the field of error of fact philosophical subjectivism imported a changed conception of error, in the field of law cognition subjectivism had first to create the very problem of error which was hitherto nonexistent.

At an early stage, the law was conceived of as a metaphysical entity, identical with morality and hence always the same in substance, certain as to existence and meaning, and self-evident to every individual. ${ }^{16}$ Within this conception of law there was no room for error. Consequently, ignorance or error of law was no defense. While such

14 See Frank, Das Strafgesetzbuch fuer das deutsche Retci (1929) 18, (rev. ed.) 188.

15 This does not affect the proposition that there is at law, strictly speaking, no such thing as a "mistake of fact". The position that each error of fact is in a sense an error of law in that it is an error concerning legally relevant facts is taken in Germany, particularly by Binding (DIE NORMEN UND ÍHRE UEBERTRETUNG [3 Bd. 1918] 121 et seq.), hy Dohna (RECHT UND IRRTUMI [1925] 26), and by Finger (LEHRBUCH DES DeUTSCHEN STRAFRECETS [1 Bd. 1904] 241). Roeder, op. cit. supra note 5, at 72, on the other hand, points out that though the law may be something given and hence real, facts need not necessarily he of legal character. The author overlooks the importance of the point of view from which the discussion is carried on. Surely, outside of the law, facts are factual and not legal. Only at law are they of legal character. The law, on the other hand, as an object of observation, for instance historical, is a fact. As the subject matter of the law concerned with error of law, the law is a relevant fact, hence again of legal nature.

${ }^{16}$ In 1606 Baron Fleming still believed that laws "can never be changed in substance". 2 Howerr's State Truals (1889) 389. 
was undoubtedly the case in the field of criminal law, the validity of the proposition has been questioned in civil law, both with respect to Roman and to certain stages of the English law. There is support for the opimion that money paid in the erroneous belief of its being due at law was as a general rule recoverable in Rome, and that it was not so recoverable only in those cases in which a condictio indebiti would not lie, for the money was in fact due and owing in good conscience though not at law. ${ }^{17}$ Similarly, there is some authority for thinking that in the English law of the eighteenth century mistake of law had a wider application as a defense than it has nowadays. ${ }^{18}$ These early positions may be but results of the original lack of distinction between mistake of law and mistake of fact, ${ }^{19}$ a corollary of the identification of truth and justice. At any rate, no certain knowledge as to their background is at present available. A rationalized rule concerning mistake of law was first enunciated ${ }^{20}$ in Bilbie v. Lum$l e y^{21}$ with its classic absurdity that everyone is presumed to know the law. This presumption is at present a generally accepted rule of law. Any deviations from it are conceived of as exceptions. ${ }^{22}$ Its philoso-

17 For a summary see Stadden, Error of Law (1907) 7 CoL. L. Rev. 476.

18 Lansdown v. Lansdown (1730) 25 Eng. Rep. 441. This case contains Lord King's famous dictum: "That maxim of law, Ignorantia iuris non excusat, was in regard to the public, that ignorance cannot be pleaded in excuse of crimes, but did not hold in civil cases." About a century later, the dictum was said not to be recognized in modern cases. Stewart v. Stewart (1839) 6 Cl. \& Fin. 911, 966.

19 Restatement, Restitution (1937) Notes on Restatement, Topic 3, p. 35: "As is well known, the distinction between rescission for mistake of law and rescission for mistake of fact originated in what many believe to be the unfortunate mistake of Lord Ellenborough in Bilbic v. Lumley, 2 East 469 (1802). Before that time no distinction was made between mistake of law and mistake of fact."

20 The Romans expressly refused to give a rationalization of the rule. Thus, Ulpian sets forth the rule for delicts, "Ignorantia excusatur non iuris, sed facti" (I, 11 \& , $D$. de his qui notantur infantia III, 2) as a maxim which requires no justification. Similarly, Paulus merely states: "Regula est iuris quidem ignorantiam nocere, facti vero ignorantiam non nocere" (I. 9. pr. D. de iur. et facti ignor. XXII, 6).

21 (1802) 2 East 469 . For a collection of American cases which follow that decision see Report of the Law Revision Commission, New York Legislative Document (1942) No. 65 (B).

22 Even the new section 112-f of the New York Civil Practice Act, which displays an extremely tolerant attitude toward mistakes of law, is so formulated as to admit rehief against such mistakes only as an exceptional measure: "When relief against mistake is sought in an action or proceeding or by way of defense or counterclaim, relief shall not be denied merely because the mistake is one of law rather than one of fact." The Senate Introductory (No. 73) and Assembly Introductory (No. 68) to the act state in a note: "Its [the bill's] purpose is not to grant relief in every case of mistake of law or to make the same rules applicable as in the case of mistake of fact. It does afford to the court, however, the power to act in appropriate cases involving a mistake of law." 
phical background, if any, is undoubtedly a metaphysical conception of the law as an object of cognition. As legal rules steadily mcrease in number and have finally become so voluminous as to render it impossible even for a professional lawyer to know all of them, the presumption conflicts with the maxim that the law requires nothing impossible. ${ }^{23}$ It is obviously unrealistic when applied to interpretations of law when even courts are uncertain. It fails to note the difference in degrees of accessibility to the knowledge of the various types of law. ${ }^{24}$ Fimally, it is utterly absurd when treating future law like presently known law, in accordance with the ancient dogma of the unchangeability of law. For reasons of policy, however, the maxim, though discredited, is maintained in principle in all legal systems. But critical elements are increasmgly noticeable, and effect is given to subjective error of law where it was considered irrelevant before.

The first departure from the presumption that everyone knows the law is carried out in an indirect manner. The term "law" is restricted to mean only general law. Error as to private rights is considered in equity as error of fact. At law, it is treated as exception. ${ }^{25}$ In the criminal law of all countries, error as to civil law is admitted as a defense in a criminal prosecution, although the differentiation between criminal and civil law is somewhat dubious and by no means uniform. ${ }^{28}$ In all cases of temporal conflict of laws increasing recognition is given to the indubitable fact that laws, and that includes statutes and their interpretation as well as cominon law, are not unchangeable, as was formerly believed. Whenever a person acts in reliance on formal authority, there is a tendency to protect him against consequences of error. Thus, where the accused acted in accordance with a decision of the state supreme court which was subsequently reversed, he was excused on the ground that he acted under a mistake of law. ${ }^{2 \pi}$ Where a defendant disobeyed an induction order in

23 Co. LrrT. 231, b. See also Stadden, loc. cit. supra note 17.

24 There is, for instance, a distinction between the possibility of acquiring knowledge of statutory and of customary law, since the two types of law are created by different methods. Hammerer remarks as to that: "Here [customary law] the law is known before it is law, there [statutory law] it is already law before it is known." DER EINFLUSS DES

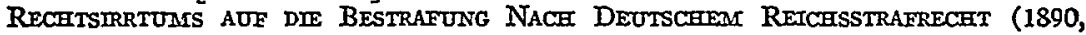
Thesis) 7. This distinction applies also with respect to the certainty of law.

25 See Winfield, Mistake of Law (1943) 59 L. Q. Rev. 327.

20 There is hardly any dispute in jurisprudential literature that the distinction is an accidental one and cannot be drawn with any amount of certainty.

27 State v. O'Neil (1910) 147 Iowa 513,126 N.W. 454. A void decree, however, is no formal authority. Thus where defendants acted in reliance on a divorce decree of a for- 
reliance on an erroneous injunction staying induction, he was held excused, the court saying: "We do not think the layman participating in a law suit is required to know more law than the judge." 28 The mere advice of counsel, on the other hand, constitutes no defense in America. ${ }^{29}$ But a Swiss court acquitted a defendant acting in violation of a statute under advice of counsel that the act was lawful. ${ }^{30}$ It seems that in America the problem is still treated from the point of view of temporal conflict between prior and later laws and decisions, rather than from the point of view of the law of mistake, ${ }^{31}$ whereas in Europe, under the influence of the numerous modern reform drafts, subjective error of law is in the stage of gaining increasing recognition as a defense.

While the law is no more considered as unchangeable, it is still regarded as "certain", in that the individual bears the risk of interpretation when a statute has not yet been judicially construed, ${ }^{32}$ and that he violates a statute believed to be unconstitutional at his peril. The burden of the latter rule is particularly unjustified, since-as seems to be the law under the rule of the recent case of United Public Workers v. Mitchell ${ }^{33}$-there is no way of testing constitutionality

eign court, held to be without jurisdiction, they were not excused. State v. Armington (1878) 25 Minn. 29.

28 United States v. Mancuso (C. C. A. 3rd, 1943) 139 F. (2d) 90, 92. Cf. State v. Chicago, Milwaukee \& St. Paul Ry. (1915) 130 Minn. 144, 153 N.W. 320. For comment see Note (1944) 92 U. of PA. L. Rev. 321.

29 United States v. Anthony (N.D.N. Y. 1873) Fed. Cas. No. 14,459 at 829.

30 The Berner court stated: "It is decisive for the court that the accused should not be made to pay when his counsel gave him erroneous advice ...." (1927). In re Kitchenmann, reported in 63 Zeitschrift des Berner Juristenvereins 265.

31. See Hall, Generat, Princtples of Criminal Law (1947) 360 et seq.

32 This is probably the reason underlying State v. Wadhams Oil Co. (1912) 149 Wis. 58,134 N.W. 1121 , where an injunction forbidding defendant's prosecution pending decision of the constitutionahty of a statute was held no defense to a prosecution instituted after the statute was upheld as constitutional for acts committed in its violation during the operation of the injunction.

33 (1947) 330 U.S. 75. In this case the complaint and affidavits of eleven civil service employees challenging the constitutionality of the Hatch Act, prohibiting them from engaging in political activities under penalty of dismissal, was held not to constitute a justiciable case or controversy. In a decision written by $\mathrm{Mr}$. Justice Reed the Court emphasized that these plaintiffs merely "declare a desire to act contrary to the rule against political activity but not that the rule has been violated". Ibid. at 88 . The complaint and affidavit of one Poole, on the other hand, was hald to present "matters appropriate for judicial determination", for Poole admitted "that he violated the rule against political activity. ..." Ibid. at 91, 93. Mr. Justice Douglas, dissenting in part (ibid. at 115 et seq.), pointed out the inequities created by the majority rule. He fully endorsed the following passage from the lower court decision: "The mere existence of the statute, saying that they [the plaintiffs] shall not engage in pohitical activity, the penalty 
except by violation. ${ }^{34}$ True, assuming jurisdiction over the constitutional issue in advance of the violation may in certain cases amount to a judicial determination of questions which are not sufficiently specific to create a justiciable case or controversy, and thus interfere with the rule against granting advisory opinions and the principle of separation of powers. ${ }^{35}$ Perhaps the conflict could be solved by permitting the violator, in a proceeding following violation, to interpose the defense of error of law as an alternative to the defense of the unconstitutionality of the statute. ${ }^{36}$

in the statute that they shall be dismissed if they do, and the waming addressed to thein by the Civil Service Colnunission in their posters certainly prevent them from engaging in such activity, if the statute is constitutional. If the statute is unconstitutional, they are being prevented froin things which they have the right to do...." (1944) 56 Fed. Supp. 621, 624. Mr. Justice Douglas continued: "But to require these employees first to suffer the hardship of a discharge is not only to make them incur a penalty; it makes inadequate, if not wholly illusory, any legal remedy which they may have. Men who must sacrifice their means of livelihood in order to test their rights to their jobs must either pursue prolonged and expensive litigation as unemployed persons or pull up their roots, change their life careers, and seek employnent in other fields. At least to the average person in the lower income groups the burden of taking that course is irreparable injury."

34 Of course, the full import of the decision in the Mitchell case is not yet entirely clear. The rule it enunciated may be said to be limited to statute violations of the particular type at issue in the case. It is doubtful that these violations may be termed as "crimes" in a technical sense. The case cited as authority in the decision (Watson $v$. Buck [1941] 313 U. S. 387) had clearly distinctive features which fully justified the action there taken by the Court. The two acts involved in this case were coinposed of forty-two separate sections, and there was "a complete absence of any showing of a defimite and expressed intent to enforce particular clauses of a broad, comprehensive and multi-provisioned statute", whose sections were severable. Ibid. at 400 . Moreover, the Court was anxious to give the supreme court of Florida an opportunity to pass upon these Florida statutes which it had not yet interpreted. A person need not commit a crime in order to contest the constitutionality of the statute creating it. Terrace $v$. Thompson (1923) 263 U.S. 197. This decision was followed by a great number of cases of which a lower court decision, New Hampshire Gas \& Electric Co. v. Morse (D.N.H. 1930) 42 F. (2d) 490 , is perhaps the nost explicit one. There the court said: "It is not reasonable to hold that a person must violate a law and subject himself to possible fines or imprisonment in order to contest the constitutionality of a statute authorizing the imposition of a penalty." Ibid. at 493. Most cases which invoke the familiar rule that courts of equity do not ordinarily restrain criminal prosecutions were decided after the crinies were already committed. The Supreine Court, per Stone C.J., implicitly recogmized the decisiveness of that fact: "It does not appear from the record that . . . a federal court of equity by withdrawing the determination of guilt from the state courts could rightly afford petitioners any protection whicls they could not secure by prompt trial and appeal pursued to this court." Douglas v. Jeannette (1943) 319 U.S. 157, 164. See also Beal v. Missouri Pacific R. Co. (1941) 312 U.S. 45.

35 This was the reason for dechining jurisdiction over the cases of the eleven plaintiffs in the Mitchell case, supra note 33.

36 To be sure, such solution would be entirely inadequate in a situation as presented in the Mitchell case, where the consequence of violation, discharge, would neces- 
There is an entire field of law in which a party's error of law is completely disregarded in America: the field of procedure. Errors and omissions of parties to legal proceedings should be treated within the general framework of the law of mistake. If procedure be anything but a "sporting contest of lawyers", mistakes in pleadings, affecting their relation to proof and judicial notice, ${ }^{27}$ as well as any other mistakes which may prejudice a party's cause without its fault, ${ }^{38}$ when brought to the attention of the court upon motion for a new trial or even upon appeal, should be permitted to be corrected. There is no

- sarily precede any court action. In an ordinary criminal case, however, it would afford some relief to a defendant honestly believing in the unconstitutionality of the statute, if such statute be held constitutional. Even here the suggested remedy cannot be said to be completely satisfactory, for a judgment of not guilty does not wipe out the stigma of a public accusation. As stated by Judge Frank, ". . . a wrongful indictment is no laughing matter; often it works a grievous, irreparable injury to the person indicted. The stigma cannot be easily erased. In the public mind, the blot on a man's escutcheon, resulting from such a public accusation of wrongdoing, is seldom wiped out by a subsequent judgment of not guilty. Frequently, the public rememhers the accusation, and still suspects guilt, even after an acquittal." In re Fried (C.C.A. 2d, 1947) 161 F. (2d) 453, 458.

37 See Morgan, Judicial Notice (1944) 57 HARv. L. REv. 269 for cases in which the trial judge's error in overlooking a statute strictly applicable to the claim of a party was held not reversible where the party failed to bring the statute to the attention of the judge. The mistake of law in cases of that nature is obviously attributable to counsel rather than to the party. In the same article Professor Morgan cites a case in which a party was clearly made to suffer for a mistaken conception of the trial judge not reversible under procedural rules, even thougl the party had brought the correct conception to the attention of the court. State v. Damm (1933) 62 S.D. 123, 252 N.W. 7. In 1931 a trial court in South Dakota was presented with the scientific issue whether parenthood is disprovable by blood tests, and defendant asked the court to take judicial notice of the fact that it is so disprovable. The court's refusal to take such notice was affirmed in 1936, on the ground that the fact, though known in 1936, was not so known in 1931. Professor Morgan remarks: "To be sure, the proposition was intrinsically as indisputable in 1931 as in 1936. The sources of indubitable accuracy, however, were not readily available in South Dakota at that time, and the parties did not furnish them. To a judge in the position of the trial judge, furnished only with the data produced by the parties, the matter appeared to be within the realm of dispute among reasonahle men, and he was right in so treating it." Within the limits of available procedural forms, no argument can be made against the correctness of the decision. There remains the fact that such procedure forced the appellate court indirectly to approve the truth of 1931 in 1936 when it had already become a falsity.

38 In Roach v. Statsny (C.C.A. 7th, 1939) 104 F. (2d) 559, the trial court was held not bound to grant a new trial upon newly discovered evidence under section 59 of the Federal Rules of Civil Procedure, after judgment on directed verdict for the plaintiff, in order to enable defendant to prove facts within his knowledge at the time of the trial, though their legal significance was not known to the defendant at such time, and though they were unknown to his attorney. Contrast with this attitude that of the English Court of Appeal which will deny a new trial only if it is of the opinion that all the facts are before the court, "and that no further evidence could be given which could alter the result. .. ." Millar v. Toulmin (1886) 17 Q.B.D. 603, 605. 
justification in their "nature" to treat them differently from so-called mistakes of fact within the meaning of the substantive law of mistake. This recognition is at present barred by the strict separation of procedure to which pleadings, judicial notice and proof belong, and substance, of which the law of mistake forms a part. It will take the combined efforts of jurisprudence as philosophy of law and natural philosophy as theory of reality to overcome the conventional separation and the inequities it creates.

The application of extreme subjectivism in measuring errors of law is incompatible with an objectivistic jurisprudential conception of law in general. But the recent jurisprudential trend to regard the law as something objective, though perhaps only in a constructive sense, is itself a corollary of the general philosophical trend to overcome subjectivism and construct an objectively valid reality. In the law of mistake this trend happens to coincide with a socialization of the law and substitution of abstract and general concepts and standards for specific and individual ones.

In accordance with that trend, the "meeting-of-the-minds" doctrine yields to the theory of expressed intent as understood by reasonable men. Not the subjective mental attitude of the promisor but such attitude as reflected in the understanding of the promisee is decisive, the promisee being thereby conceived of in abstracto, as the constructive representative of a group of potential observers. ${ }^{39}$ This transformation of the law is carried out gradually, and frequently not in a jurisprudentially perfect and clear-cut manner. Often, the law still partially clings to old jurisprudential forms and adjusts results coinciding with new trends by the use of indirect methods. For example, the Swiss law, ${ }^{40}$ while adopting the doctrine of expressed intent (doc-

39 "It does not follow that because there has been a mutual mistake there can be no consensus." Cheshire, Mistake as Affecting Contractual Consent (1944) 60 L. Q. Rev. 175, 178. "The current phrase, 'the intention of the parties governs the contract', is really only true to this extent: that it governs the contract where both parties are agreed what the intention was. Where there is a dispute as to the intention, the contract, or rather the contractual hability, is governed by the intention, as it is presumed from that sense which, under all the circumstances, the judge thinks ought fairly to be attached to the promise." The judicial standard is that of a "reasonable man". MARKBY, EIEMIENTS of LAw (1905) $\$ 622$ (quoted in Cheshire, supra).

40 Simonius, Wandlung der Irrtumslehre in Theorie und Praxis, in Festgabe zum siebzigsten Geburtstage von Fritz Goetzinger (1935) 10 BASLER STUDIEN zUR RECHTSwISSENSCHAFT 240 et seq. Von Tuhr/Siegwart interprets the law as adopting a compromise between the theory of subjective intent and that of the declared intent. Arrcearener Tem des Scewweizerischen Obligationenrechis (zweite ergaentze Aufl, 1942) 269. 
trine of reliance, Vertrauenstheorie) as principle of contract formation, still preserves the subjective intent doctrine as basis of its law of mistake. The practical results of the adherence to the old doctrine, however, are negligible, since due to the prevailing rules as to burden of proof, that doctrine was never very effective in practice.

In criminal law the requirement of subjective identification of the specific object toward which the action is directed is set aside, ${ }^{41}$ and what is required is solely such amount of knowledge on the part of the actor as is necessary to constitute the moral reprehensiveness of the criminal intent. All the actor must be aware of is that the victim is a human being. It is incorrect to speak of an error in obiecto when the actor injured $B$ when intending to kill $A$, since the legal object is the same - a human being. ${ }^{42}$ This change of legal conception is, of course, also attributable to a changed social philosophy which declares the human being in abstracto rather than the individual person to be the object of legal protection.

So far as error of law is concerned, the trend toward objectivity calls for a differentiation between acts which, according to some general standard, can be recognized as probably prohibited, and acts whose prohibition is not so discernible. Accordingly, error of law is no defense in the case of violation of a statute forbidding an act in itself immoral; it is otherwise when the statute at issue enjoins a mere malum prohibitum, ${ }^{43}$ the prohibition of which a defendant cannot be expected to presume. A historical standard or the constructive stand-

41. The error, to be sure, is not entirely devoid of legal significance. Aggravating circumstances attaching to the injured person are not imputed to the actor, and extenuating circumstances which are peculiar to the person intended to be harmed are considered although they do not obtain in the case of the actually injured person. For a summary of the literature on the Italian law of error in obiecto see Hackel, op. cil. supra note 13. Nor is the development, as here described, strictly historical. In America the attitude varies in the different jurisdictions rather than at different periods of time. Those jurisdictions which adopted the position of subjective identification are still adhering to it. Thus, for instance, the differentiation between error in obiecto and aberratio icthes is maintained in Missouri cases. For a comprebensive discussion see State v. Martin (1938) 342 Mo. 1089, 119 S.W. (2d) 298.

42 Alimena distinguishes between errore essenziale and errore accidentale. I LuMrrI E I Moeificatori detl 'IMPUTabitita (1896) 372 et seq. Error consisting in the confusion of two human individuals is an errore accidentale, for the essential element is the human being, whether A or B. For that reason, Alimena, like Perroni-Ferrauti (Dex. Nesso Causale E Delia sua Imputazione [1888] 57), believes that the term error in obiecto is incorrect, for the oggetto gintridico is the human being in general, hence the person intended to be injured and the one actually injured are legally identical objects.

43 Miller, op. cit. supra note 12, at 159, 160. 
ard of the reasonable man will have to be applied in determining when an act can be regarded as in itself immoral.

In general, the law of mistake nnay be said to be at present in a state of flux and hardly to form a systematic whole. Increasing recognition is given to error. But what ought to have been known is treated as equivalent to the known, the law being, in principle, regarded as belonging to the former category. The trend is toward objectivity and generalization. No sufficient account is taken of the various degrees of accessibility of the knowledge with which an individual is charged.

The law distinguishes between various objects of cognition, without there being any justification in their nature for such distinction. It thus discriminates between error of fact and error of law, and within the sphere of the latter it differentiates between substantive error and error in procedure.

In spite of these shortcomings when judged in the light of natural philosophy, it may be fair to say that whatever progress has been achieved in law is partially attributable to natural philosophy. To be sure, there is no tangible evidence that such is the case. The similarity of the legal and the philosophical development, however, can hardly be accidental.

\section{THE LAW OF RELIGIOUS BELIEFS AND THEIR REALITY}

The law of religious beliefs and their reality is generally considered as utterly unrelated to the law of mistake and its reality. In philosophy, however, the corresponding fields merely afford different answers to the same questions. In dealing with objects of the outside world, the law may assume a particular religious philosophy of nature. This practice is best exemplified by the laws of ancient and medieval theocracies. ${ }^{44}$ The present legal approach to religion, to be sure, is predominantly determined by the social rather than the natural philosophy of a particular form of government. The object of protection is the personality of the believer rather than the content of his creed. ${ }^{45}$ Recently, however, the Supreme Court of the United States has had occasion to discuss the legal relation of creed to its content, and thus it reached the philosophical implications of the problem.

44 A discussion of ancient, medieval, or any other laws outright based on religious concepts, will be omitted liere. Such laws accept definite religious philosoplies of nature. Whether sucl plilosoplies determine their legal rules or are rather determined by them is an intricate tlieological problem; there is no room in this context for such a discussion.

45 Otherwise, it would be indeed difficult to justify the simultaneous protection of different and mutually exclusive religions. 
The crucial issue of United States $v$. Ballard ${ }^{40}$ was not ultimately disposed of in that case. It is the formulation of a functional definition of religion as an object of protection by the First Amendment. The very operation of the Amendment is predicated upon the existence of religion as a factor in the case. The existence of religion is a jurisdictional fact. Hence, unless and until a functional definition is given, litigation in the matter of Ballard will never come to a close, as distinctly noted by Mr. Justice Frankfurter in his dissent in the second Ballard case. ${ }^{47}$ Of course, it would be erroneous to assume that since

46 (1944) 322 U.S. 78. Defendants were charged with using the mails to defraud by the propagation of a purported religious movement known as the "I Am" movement. The teachings of this movement included defendants' communication with supernatural entities, such as shaking lands with Christ and taking dictation from Him, resulting in the cure of diseases, procurement of wealth, etc. The fraudulent scheme was alleged to consist in causing the persons intended to be defrauded to purchase literature, make gifts, etc.; the particular inducement was the inculcation of the belief in the near advent of a cataclysm which renders worldly transactions, such as saving money and building homes, illusory. Defendants demurred to the indictunent and were tried. Upon trial, defense counsel agreed that the issue of the truth or falsity of the content allegedly believed in be withdrawn from the jury and that the jury pass only upon the question of whether defendants actually believed in the things they professed to believe. The jury, instructed to that effect by the trial court, rendered a verdict convicting the defendants. Upon appeal, the circuit court reversed the judgment upon the verdict; the inajority, per Judge Matthews, ruled that the crime with which defendants were charged consists of two material elements, falsity of the belief and falsity of the facts allegedly beheved $m$, and that it was accordingly reversible error to withdraw the issue of the latter from the jury. Ballard v. United States (C.C.A. 9th, 1943) 138 F. (2d) 540. Judge Denman, on the other land, concurring in the denial of a petition for relearing, was of opinion that the withdrawal deprived defendants of the opportunity to prove the truth of what they beheved in as relevant to the issue of the belief itself. He said: "It would be strong evidence in support of this issue of the mental condition of behef, that these transactions with Jesus actually occurred in their presence. The right to produce such evidence was demed appellants . . . The district court did not give its reason for its ruling and instruction. If the reason be because such facts could occur in no possible chain of natural material causation, it is a denial to the religious of the riglt to prove one of the bases of their belief in the intervention of the supernatural in the daily lives of human beings-an obvious denial of the freedom of religion of the First Amendment of the Constitution." Ibid. at 546. On certiorari, the Supreme Court of the United States reversed the circuit court, and sustained the ruling of the district court. It remanded the case to the circuit court to enable it to pass on other questions (composition of jury) argued by defendants but not disposed of upon tbe first appeal. The case thus reached the Supreme Court for the second time. Ballard v. United States (1946) 329 U.S. 187.

47 Ibid. at 200, 201. Justice Frankfurter points out that the "central issue" before the Court was not decided, for the case "was remanded to the Circuit Court of Appeals without considering the question whether the First Amendment affords immunity from criminal prosecution for the procurement of money by false statements as to one's religious experiences." 
the opinion in the first Ballard case offers no definition of religion, the case contains no such definition. A definition of the object of protection is implied in every judicial decision. It may be, however, too general to cover and delimit further litigation. What is needed is not just a definition, but a functional one. Such definition, for purposes of the law, is one that combines substantive and procedural aspects. In this instance it inust answer not only the question, what is religion, but also the question, when can it be said that a religion exists at law, and that means, how can the existence of religion be proved. It can hardly be contested that the most important component of the substantive concept of religion within the meaning of the First Amendment is the element of belief. The real legal problem is: how can belief or its lack be shown. Is it possible to prove or disprove belief independently of its content? Mr. Justice Jackson in the first Ballard case clearly formulated the issue in raising the question as to whether it is possible to separate what is believed from considerations as to what is believable. ${ }^{48}$ Citing William James, he answers the question in the negative.

If, as stated by Mr. Justice Jackson, the determination of the truth or falsity of facts on which religious beliefs are based is essential to the issue of belief itself, and if, as was held in the case, such determination is inaccessible to court or jury, then remanding the case is an idle gesture. ${ }^{49}$ Moreover, it must be equally impossible for any court or jury in any case to try the issue of religious belief, and the mere allegation by a defendant that the acts with which he is charged are carried out in pursuance of a religious belief is necessarily sufficient to

48 (1944) 322 U.S. at 92 . "In the first place, as a matter of either practice or philosophy I do not see how we can separate an issue as to what is beheved from considerations as to what is believable. The most convincing proof that one believes his statements is to show that they have been true in his experience. Likewise, that one knowingly falsified is best proved by showing that what he said happened never did happen. How can the Government prove these persons knew something to be false which it cannot prove to be false? ... it seems to me an impossible task for juries to separate fancied ones (communications with the Unseen) from real ones, dreams from happenings, and hallucinations from true clairvoyance. ... And then I do not know what degree of skepticisin or disbehef in a religious representation amounts to actionable fraud. James points out that 'Faith means belief in something considering which doubt is still theoretically possible'."

49 To be sure, the full scope of the issue involved in the case was not properly before the Court. In his dissent, Mr. Chief Justice Stone clearly emphasized this point: "There are no exceptions to the charge and no contention that the trial court rejected any relevant evidence which petitioners sought to offer. Since the indictment and the evidence support the conviction, it is irrelevant whether the religious experiences alleged did or did not in fact occur or whether that issue could or could not, for constitutional reasons, have been rightly submitted to the jury." Ibid. at 89 . 
constitute religion within the meaning of the Amendment and to dismiss any indictment. This amounts to the adoption of an extreme subjectivism which leaves to the individual not only the ethical choice of belief but also the ultimate cognitive determination whether the attitude at issue is a belief. Nor could Mr. Chief Justice Stone's suggestion as to how the truth of religious beliefs can be disproved without involving the issue of the facts on which they are allegedly based remedy the difficulty. ${ }^{50} \mathrm{He}$ was of opinion that a distinction must be made between purely religious mystical communications with the Unseen and collateral outward facts of experience. While it is inadmissible, since impossible, to disprove the fact that Ballard shook hands with Christ, it would be possible to show that he never was in San Francisco, and hence the handshake could never have occurred there, as claimed. Within the subjective experience of Ballard, however, his presence in San Francisco is a mystical event by no means of a different nature from his shaking hands with Christ. The inherent universalism of religious truth covers both, and the conventional reality of the law of evidence cannot be opposed to former and latter alike.

Whatever objections may be raised against Mr. Justice Jackson's conception of religious freedom, ${ }^{61}$ there is no denying the fact that nothing short of such a conception can take full account of what religions themselves regard, or at least may regard, as their essential elements. The subjective cognitive finding by an individual that what

50 Ibid. ". . . if it were shown that a defendant in this case had asserted as a part of the alleged fraudulent scheme, that he had physically shaken hands with St. Germain in San Francisco on a day named, or that, as the indictment here alleges, by the exertion of his spiritual power he thad in fact cured ... hundreds of persons afflicted with diseases and ailments,' I should not doubt that it would be open to the Government to submit to the jury proof that he had never been in San Francisco and that no such cures had ever been effected. ..."

51 The main objection is that set forth by Green. He says: "It would be pleasant to 'have done with this business of judicially examining other people's faiths,' hut if by that is meant the business of examining, not the truth of the religion, but the genuineness of the belief in it, the Court can never have done with that so long as enforcement of the First Amendment remains necessary. If the freedom guaranteed to the exercise of religion is to survive, it must be restricted, somehow, to those who genuinely believe and exercise their rebigion under the inexorable compulsion of their belief. Neither frand, nor child labor, nor any secular enterprise becomes entitled to this freedom by simply putting on the dress of religion. Nothing could be more devastating to real religion than the imphication mentioned above; nor could anything be more destructive to religious freedom, in the long run, than to extend its inmmities to whomever claimed them, without enquiry when the claim appeared fraudulent. And the enquiry is perhaps not so difficult as Justice Jackson fears. . . . One can doubt the belief without doubting the believer." (Italics added.) Liberty Under the Fourtecnth Anvendment: 1943-44 (1944) 43 MrCH. L. REv. 437, 454. 
he believes in is a religion, and that he is a believer, may be part of his religious creed, and thus, the protection of such finding from challenge may be said to be a necessary part of full religious freedom.

Nor does Mr. Justice Jackson's attempt to do full justice to the content of creed stop at this point. As indicated in his concurring opinion in the second Ballard case, ${ }^{52}$ he believes the crime of mail fraud with which defendants were charged to be composed of two material elements, "a provably false representation in addition to knowledge of its falsity." The falsity of the facts alleged to have taken place is, in his opinion, inadmissible in evidence even for the purpose of establishing the first mentioned element of the crime, that is, within the framework of a separate legal issue which, as ultimate proposition, contains no elements of subjective belief in its defimition.

The issue raised by Mr. Justice Jackson seems to be still open. According to Mr. Justice Douglas, ${ }^{53}$ the holding of the first Ballard case merely consisted in the reversal of the circuit court and the sustaining of the district court's ruling that the truth or falsity of facts allegedly believed in be withdrawn from the jury. The question whether such truth is essential to prove genuineness of belief was not disposed of, particularly in view of the fact that defense counsel had agreed that it be withdrawn. ${ }^{54}$ In ultimately deciding the question, however, the Supreme Court will have to face the unavoidable fact that if deprived of the possibility of proving such truth, the alleged believer is placed in a worse position than any other litigant charged with fraudulent misrepresentation.

The issue as now presented seems to involve an alternative between the extreme subjectivism of Mr. Justice Jackson and a moderate subjectivism expressed in entirely eliminating the issue of the truth of religious facts from the scope of the legal concept of belief. It is submitted that an intermediate solution could be reached. To do so would require investing the conventional procedural law of evidence with a now absent substantive ineaning.

62 "This Court previously ruled that it is improper for the trial court to inquire whether the religious professions and experiences as represented by defendants were true or false but that it can inquire only as to whether they were represented without belief in their truth. This leaves no statutory basis for conviction of fraud and especially no basis for conviction under this indictment. It requires, in my opinion, a provably false representation in addition to knowledge of its falsity to make criminal mail fraud. Since the trial court is not allowed to make both findings, the indictment should be dismissed." (1946) 329 U.S. 187, 196.

63 See his opinion in the second Ballard case, ibid. at 188.

-4 Supra note 46. 
The procedural proposition that evidence to show existence vel non of the occurrences alleged to be the basis of belief is inadmissible has at present no substantive meanmg at all. Translated into substantive terms, it may have a number of meanings: (1) the allegation that the occurrences actually happened is not untrue; (2) such allegation is true; (3) it is true as referring to the content of the individual experience. The last mentioned meaning obviously was not the basis of decision. From the point of view of legal evidence, such allegation would be tautological; it would be equivalent to the proposition that defendants believed in such occurrence, which, as such, was denied by the finding of the jury. The occurrence of the facts allegedly believed in is undoubtedly conceived of as an independent evidentiary proposition relevant to belief. If so conceived, its inadmissibility in evidence may have only one of the two first mentioned substantive meanings. It would have the strongest substantive import if it were assumed to have the second indicated meaning, namely, if it were understood as an irrebuttable presumption that such occurrence actually took place. Such presumption would not finally dispose of the issue of belief, for just as it is possible to believe in something that is not true, so is it possible that a person should disbelieve something that is true. To be sure, the proof of disbelief in true facts is a rather difficult task, but it cannot be said that under no circumstances can such proof be made. ${ }^{55}$ Had the trial judge instructed the jury in accordance with the suggestion submitted here, the defendants would be afforded the best imaginable protection, for they could utilize the evidentiary value of the truth of the alleged facts to prove belief to the utmost extent. Yet, the prosecution would still have some chance, however remote, to succeed by showing disbelief in the facts presumptively true, whereas it is obviously denied even that slight chance under the rule set forth by Mr. Justice Jackson.

If statutory mail fraud requires in addition to disbelief falsity of the represented facts, there is no conceivable reason for extending the protection guaranteed so far as the former issue is involved to the latter issue. In that latter issue belief, and hence religion, has no part.

55 The lack of belief could be proved by showing any conduct on the part of the Ballards wlich is incorsistent with belief. It could be shown, for instance, that the Ballards did buy lomes, save money, etc., in short, carried on transactions which were inconsistent with their alleged belief in the near advent of a cataclysm, as predicted by them. The lack of belief also could be shown by admissions. Such possibility is not too farfetched, and especially in a case of conspiracy where the admission of one defendant is attributable to all the others, a conviction of several defendants may thus be obtained. 
At law it is possible to treat the alleged occurrences as irrebuttably true for the purpose of showing belief, while at the same time as untrue or provable to be untrue in themselves, as ultimate material propositions. Simce belief is not involved, Mr. Chief Justice Stone's device can certainly be used in this context. Here Ballard's presence in San Francisco has no mystical implications, and it may be shown that he never was there, that hence the alleged facts could not have occurred, though it may be impossible to show directly even within such limits that he never commumicated with Christ.

An objection to such a solution may be raised on the ground that, in nature and logic, the allegation that an occurrence took place cannot be true and false at the same time. At law, however, such contradictory propositions are, in general, admissible. Mr. Justice Jackson, in fact, does not raise such objection, but rather proceeds from an independent assumption that just as the facts relied on are essential to belief, so, on the other hand, these facts do not exist outside of belief and cannot be proved or disproved apart from it. That they are not believed in cannot, on the other hand, be proved without showing their intrinsic falsity. Obviously, the resulting situation is rather hopeless. What is solely important in the present context, however, is the assumption that at law the alleged mystical occurrences are true if believed in, since not independently disprovable. Thus, a definite though general legal-philosophical interpretation of the contents of belief, a subjectivistic "religious" philosophy of nature, is introduced.

This carries over to a second aspect of religious freedom. Does government, may government, have a "religious" philosophy of nature of whatever kind, whether general or specific?

As stated by Mr. Justice Douglas in the Ballard case, ${ }^{56}$ the First Amendment has a dual aspect. It provides (1) that there can be no heresy at law, so that the individual may freely adopt any religion he chooses; (2) that the government is committed to the support of no dogma, the establishment of no sect, or in other words, that the Constitution of the United States adheres to the principle of separation of church and state. This separation may mean either that government refuses support to particular religious philosophies, or that it adopts

$56 \mathrm{Mr}$. Justice Douglas makes the following statement which forms the essence of his opinion in the case: "The law knows no heresy, and is committed to the support of no dogma, the establishment of no sect.' Watson v. Jones, 13 Wall. 679, 728. The First Amendment has a dual aspect. It not only 'forestalls compulsion by law of the acceptance of any creed or the practice of any form of worship' but alşo 'safeguards the free exercise of the chosen form of religion.' Cantwell v. Connecticut, 310 U.S. 296, 303." (1944) 322 U.S. 78, 86. 
no religious philosophy of any kind, however general and undiscriminatory against any particular religion. In the constitutional law of the United States this question is still an open one.

In Washington ex rel. Clithero et al. v. Showalter et al., ${ }^{\mathrm{gT}}$ the Supreme Court of the United States dismissed for the want of a substantial federal question an appeal from a decision of the supreme court of the State of Washington, ${ }^{\text {,s }}$ upholding the refusal of the Washington State Board of Education to consider a petition for the introduction of Bible reading in schools on the ground that such action would violate the constitution of Washington. The Supreme Court of the United States thus held a state law prohibiting religious education in public schools as not unconstitutional within the meaning of the Federal Constitution.

Language in both the majority opinion and the dissent in the recent case of Everson v. Board of Education of Ewing $T p{ }^{50}$ indicates that a statute imposing the duty of teaching a particular religion in public schools would be unconstitutional. But what attitude would the Supreme Court adopt toward statutes which do not introduce the teaching of any particular religion but merely protect a general religious philosophy of nature against criticism?

Unfortunately, the notorious case of Scopes v. State ${ }^{00}$ never reached the Supreme Court. It involved the constitutionality of the Tennessee Anti-Evolution Act prohibiting the teaching in public schools of theories that deny the divine creation of man. The supreme court of Tennessee declared the Act not to be violative of the due process clause of the Federal Constitution. ${ }^{61}$ Of the opinion in the

57 (1931) 284 U.S. 573.

58 (1930) 159 Wash. 519, 293 Pac. 1000.

59 (1947) 330 U.S. 1.

60 (1926) 154 Tenn. 105, 289 S.W. 363. Scopes was convicted upon indictment under the Tennessee Anti-Evolution Act "for that he did teach in the public schools of Rhen county a certain theory that denied the story of the divine creation of man, as taught in the Bible, and did teach instead thereof that man had descended from a lower order of animals."

61 It was also held not to violate the law of the land clause of the Tennessee constitution, asserted to he identical in scope with the due process clause. Mr. Chief Justice Green, writing for the majority, based the decision on the theory that $\mathrm{m}$ passing the statute, Tennessee did not act under its police power but rather as a corporation, a proprietor or employer. As master to servant, it prescribed to Scopes the character of work he shall or rather shall not perform. A complete answer to this contention is given in the dissenting opinion of Mr. Justice Frankfurter in West Virgima State Board of Education et al. v. Barnette et al. (1943) 319 U.S. 624, 660. "All citizens are taxed for the support of public schools although this court has denied the right of a state to compel all children to go to such schools. ..." 
case only that of Justice Chambliss deserves attention. He proceeds from the proposition that there are two theories of organic evolution, a theistic and a materialistic one. Only the latter which infers from the theory of evolution the denial of divine creation of man is barred from the Tennessee public school curriculum. Such denial, however, is not essential to the teaching of the theory of evolution. If interpreted in the light of the theistic approach, sanctioned by the Declaration of Independence and by the Constitution of the United States, this theory in all its biological aspects is permitted to be taught. In not imposing the teaching of the Bible im public schools, on the one hand, and in prohibiting the teaching of any denial thereof, on the other, Tennessee adopts an attitude of strict neutrality toward religion, and thereby adheres to the principle of separation of church and state.

Theism which is thus declared to be the state religion of the United States, of course, is a religion. It is perhaps even a particular religion from the moment it integrates the general truths of all religions into one system. In the last analysis, there is no religious philosophy of any kimd, however general and undiscriminatory, which could not be interpreted as a particular creed, and which could not result, under any circumstances, in discrimination against any particular future religion. The question then cannot be cast-as clearly stated by $\mathrm{Mr}$. Justice Rutledge ${ }^{62}$-in terms of legal discrimination or its absence, for this is only a secondary aspect of religious freedom. The broader proposition is one of "identification" of state with religion, however "comprehensive", or of its denial. There can be no true individual religious freedom where government itself has a religion or a religious philosophy of any kind, however general. The two aspects of religious freedom emphasized by Mr. Justice Douglas ${ }^{\theta 3}$ are inseparably connected with each other.

It follows from the foregoing that Scopes $v$. State should have

62 Dealing with financial state aid to religious education, Mr. Justice Rutledge stated in lis dissent in the Everson case: "The Amendment's purpose was not to strike Inerely at the official establisliment of a single sect, creed or religion, outlawing only a formal relation such as liad prevailed in England and some of the colonies. Necessarily it was to uproot all such relationships. But the object was broader than separating church and state in this narrow sense. It was to create a complete and permanent separation of the spheres of religious activity and civil authority by comprehensively forbidding every form of public aid or support for religion. . . . The problem then cannot be cast in terms of legal discrimination or its absence. This would be true, even though the state in giving aid should treat all religious instruction alike. . . . The Constitution requires, not comprehensive identification of state with rehigion, but complete separation." 330 U.S. at $31,59,60$.

63 Supra note 56 . 
been reversed. By the same token, Mr. Justice Jackson's position that the legal issue of the truth of religious facts, as an issue independent from the legal element of belief, is inaccessible to the jury, is open to doubt, for it involves a governmental concept of religious truth.

However the Court may finally dispose of the issue presented in the Ballard case, in deciding this issue, it will have to cope with problems of natural philosophy. One element is clearly apparent already at this stage. Within the sphere of individual religious freedom careful consideration is given to the impossibility of acquiring knowledge at least concerming the content of belief within the legal issue of such belief. Whether due to the present form of the concept of inadmissibility of evidence, this inaccessibility of knowledge will be extended to cover the entire issue of belief; whether under the influence of philosophy, it will operate also outside of the issue of belief itself, still remains to be seen. If the problems raised are disposed of in accordance with Mr. Justice Jackson's suggestions, the procedural cognitive element will indeed shape the substance of the right of religious freedom. At any event, the recognition in this sphere of law of the importance of accessibility of knowledge and perhaps also of its context and various stages may be contrasted with the disregard of the problem of access to knowledge and its various degrees in the law of mistake.

\section{THE LAW OF SCIENTIFIC FREEDOM AND SCIENTIFIC "REALITY"}

Unlike religions, sciences have no reality concept of their own. Their methods and results are independent of, and indeed unconcerned with any philosophical or religious doctrine of reality. ${ }^{64}$ They may come in conflict with such doctrine only so far as it is not merely philosophical but attempts to be scientific in denying scientifically established facts and generalizations. The philosophical function of science is thus negative. Science may withdraw the factual basis on which a particular philosophical or religious thesis is built, and thus indirectly controvert such thesis. In so doing, it negatively expresses a limited philosophical view. When faced with a conflict of that type, the law must take a position, be it only one of neutrality. It thus gives effect, in a positive or negative sense, to a natural philosophy.

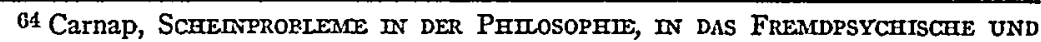
DER REALISMUSSTREIT (1928). Carnap sets forth as example of the independence of science on any particular conception of reality the case of two geographers, of whom one is an epistemological idealist and the other a realist, assigned to give a geographical report on a newly discovered mountain. It will be found, the author says, that their measurements, descriptions, etc. will be exactly the same, even though they may disagree on the question whether or not the mountain has an existence independent of its being perceived. 
Such is the issue of the above discussed case, Scopes v. State.$^{65}$ It is, as stated, in terms of American federal law, still an open issue. It has received, however, undue international publicity through the recent challenge of Mia Ehrenburg. In a statement which is undoubtedly a masterpiece of journalistic skill he contrasted the American concept of freedom with the Russian one. In comparing the Russian prohibition of teaching anti-Marxian ideas with the Tennessee restriction upon the teaching of the theory of evolution, he posed the question which of the two provisions is the more objectionable one. From the point of view of a truly scientific approach, the answer must be that they are equally objectionable. Marxism is in the first place an economic theory of evolution, a scientific theory setting forth causal economic laws, and only subsequently a political doctrine. As a scientific theory, this doctrine as well as any denial thereof is comparable to the biological theory of evolution, and it is indeed difficult to see on what grounds a distinction can be made between the two prohibitions. True, the fact that the Russian prohibition is not better cannot be regarded as a justification. It should be noted, however, that even the opinion of the supreme court of Tennessee in the Scopes case cannot be regarded as a strict holding within the meaning of American jurisprudence. Scopes' conviction under the Anti-Evolution Act was not upheld. The indictment was rather disposed of by a nolle prosequi. There is no doubt whatever in the mind of the present writer that the Supreme Court of the United States would have declared the statute unconstitutional. Note that in American constitutional law freedom of science is not a specific concept $t^{\text {G6 }}$ but part of the general concept of freedom of thought. ${ }^{67}$ It has been held that freedom of thought is coextensive with that of religion. ${ }^{68}$ It follows that while the state, through its public schools, may not impose a religious philosophy of nature, neither may it exclude any secular philosophy, such as the materialistic one. As between such various philosophies, the state stands

\footnotetext{
65 Supra note 60.

66 Freedom of science, as a distinct and separate civil liberty, is contained in several constitutions of continental Europe.

${ }^{B 7} \mathrm{It}$ is also included within the liberty concept of the due process clause.

68 "The First Amendment gives freedom of mind the same security as freedom of conscience. . . G Great secular causes, with small ones, are guarded." Thomas v. Collins (1945) 323 U.S. 516, 531. Cf. Follet v. McCormick (1944) 321 U.S. 573, 582, Justices Roberts, Frankfurter, and Jackson, dissenting: "It will not do to say that the Amendment, in the clause relating to religion, is couched in the imperative and, in the clause relating to freedom of speech and press, is couched in the comparative. The Amendment's prohibitions are equally sweeping."
} 
neutral. ${ }^{69}$ Part of the education conveyed to students in the public school curriculum is the general factual information that such divergent views exist. Indoctrination in any particular view, however, is barred.

Another aspect of scientific freedom is more properly concerned with scientific truth than with scientific reality, if any. Within the scientific knowledge available at any given time, it is possible that two contradictory scientific opinions may be reasonable. Philosophy dealing with sciences is well aware of that fact and may even consider it in arriving at its reality concept. The history of science discloses that like religious heresy, scientific nonconformance has often proved to be a great promoter of culture. Does the law take account of this situation? 70

In United States v. Ballard Mr. Justice Douglas emphasized as the very essence of religious liberty the proposition that "the law knows no heresy, and is committed to the support of no dogma, the establishment of no sect."II In the realm of science the same holds true with respect to the mere expression of scientific opinions by speech, teaching and writing. But when it comes to the practice of such opinions, scientific freedom falls far short of religious freedom. The state may not adhere to any specific religious creed but it holds scientific opinions, acts in accordance with them in the exercise of police power, and enjoins individual actions contrary to such opinions. Although, as was said in Thomas v. Collins, " 'Free trade in ideas' means free trade in the opportunity to persuade to action, not merely to describe facts", yet in Lambert $v$. Yellowley ${ }^{73}$ individual freedom of scientific activity was restricted to those cases where the opinion on which the activity is based is supported by established scientific authority. Because no such support was shown, protection was denied. How large the support must be for an opinion to be protected is not clear.

Even an opinion supported by the overwhelming weight of scientific authority, however, may not prevail against the government acting as proponent of a scientific view in the exercise of police power.

${ }^{69} \mathrm{~A}$ public school teacher who abuses his position to impose on the students his own religious or philosophical views at the expense of other possible views should be disqualified.

To For purely technical reasons the law sometimes rejects an undisputed scientific truth of today and accepts an already discarded scientific view. Supra note 37.

71 Supra note 56.

72 (1944) 323 U.S. 516, 537.

73 (1926) 272 U.S. 581. In this case a pliysician claimed that his freedom to practice medicine was unduly restricted by a statute confining the right to prescribe alcohol to definite amounts. 
In Gardner v. Massachusetts ${ }^{\text {T4 }}$ the prosecution's view prevailed on the sole ground that the prohibited medical remedy at issue in the case was not an exclusive one but that an alternative was available; the prohibited remedy was one advocated by the great weight of medical authority, whereas the alternative was not recommended even by a substantial number of the medical profession. ${ }^{75}$ True, in such instances the values protected by the state are not exclusively medical. The state is concerned not only with the health but also with morals of the people, and may weigh considerations of the former against those of the latter. But value conflicts of that nature equally obtain where religious freedom is at issue, and the interest of the state to prevent fraud is no less important than its interest in barring immorality. Surely, a physician's freedom to give reasonable medical advice, in accordance with his best medical judgment and the dictates of his medical conscience, to persons seeking such advice, is as worthy of protection as the freedom of offering unsolicited religious advice. ${ }^{76}$

The American law of scientific freedom is at present in a far from satisfactory state. Comparison with the law of religious freedom

74 (1938) 305 U.S. 559. In this indictunent under a Massachusetts statute prohibiting the use, sale and prescription of contraceptives (9 Mass. LAws [Michie, 1933] c. 272, \$21), the defendants, a doctor and nurses in a charity hospital, offered to prove that all the medicines, drugs, etc. at issue in the case were intended for use only upon prescription by a duly qualified physician in instances where such use was necessary for the preservation of the life or health of the patients, according to sound and generally accepted medical practice. Since this offer of proof was rejected, the Supreme Judicial Court of Massachusetts accepted, under a conclusive presumption, that the defendants would have succeeded in proving all that they offered to prove. It nevertheless held the statute constitutional with respect to defendants. Commonwealth v. Gardner (1938) 300 Mass. 372,15 N.E. (2d) 222. The Supreme Court of the United States dismissed the appeal from the judgment upholding the conviction for the want of a substantial federal question.

is The following cases were relied on by the Supreme Court: Lambert v. Yellowley, supra note 73; Graves v. Minnesota (1926) 272 U.S. 425 (rejecting the undoubtedly unreasonable clain of freedom to practice dentistry without diploma of an approved dental college); Jacobson v. Massachusetts (1905) 197 U.S. 11 (denying defendant's right to be exempt froin a vaccination requirement, wbere all that the defendant succeeded in showing was that he, a layman, did not believe in vaccination); Powell v. Pennsylvania (1888) 127 U.S. 678 (upholding a statute prohibiting the sale of oleomargarine, where plaintiff nerely showed that his own product was wholesome but adduced no proof that other such products may not be unwholesome, and where the freedoin of science was not actually involved). These were the authorities which were held to dispose of Gardner v. Massachusetts so thoroughly as to require no further analysis and dispense with the necessity of oral argument, in short foreclose the existence of a "substantial federal question".

76 In Tileston v. Ullman (1943) 318 U.S. 44, a case arising under a Connecticut statute (CONN. GEN. STAT. [1930] $\S \S 6246,6562$ ) and involving issues substantially similar to those of the Gardner case, the question of scientific freedon of the physician was held not to be properly before the Court. This holding was due to a defect in pleadings which alleged that the statute was unconstitutional as apphed to the physician 
makes this observation particularly evident. Whereas in the latter body of law full recognition is given to the cognitive element in that facts inaccessible to knowledge are eliminated, and thus subjective opinions are protected, no room whatever is left in the former body for divergent opimions and their practice, even though such opinions may reasonably be held within the limits of available knowledge. To the extent of the similarity in this cognitive aspect between religion and science, similar rules should prevail in the two fields, and reasonable scientific opinions should be protected. In other respects, rules goverming the two fields may be arrived at from their contrast. Since only reasonable scientific opinions should be protected, and reasonableness of such opimions can be objectively tested, it nuay be unnecessary here to require as stringent a proof of the genuineness of the belief, unless it be to supplement a minority view. In the law of religious freedom, on the other hand, where no objective test of reasonableness is available, proof of the genuineness of belief is essential. Since, in contrast to a religious doctrine, a scientific theory does not hold itself out as infallible, sufficient testing before practice may be required. Needless to add that while a religious opinion is not legally conditioned upon any qualifications on the part of its holder, a layman should not be entitled to protection of activity, positive or negative, based on a "scientific" opinion, the understanding and evaluation of which requires positive scientific knowledge. ${ }^{7 T}$ Within such limits and subject to the doctrine of clear and present danger, however, freedom of scientific opinion and activity should be coextensive with religious freedom. ${ }^{78}$ In deciding the issue of scientific freedom, the courts should bear in mind that this is the freedom for which Galileo died as a heretic.

\section{CONCLUSION}

In the three fields of law discussed in this paper one common problem is noticeable, i.e., the legal treatment of the unknown. The

since it violated the clause prohibiting the taking of "life" without "due process" instead of alleging the taking of "liberty". Of course, the preservation of a patient's life is an important element in the physician's professional "liberty" interest. The case was decided on the ground of a mere misnomer in the pleadings.

$\pi$ Jacobson v. Massachusetts, suspra note 75 . In this case defendant should have invoked other civil liberties as defense.

is The rule of scientific freedom advocated here may be thus summarized: a person qualified to hold a reasonable scientific opinion, and genuinely believing in the scientific validity of such opinion, should be entitled to exercise it freely, provided that such opinion is in fact reasonable, and that he does not so exercise it as a mere experiment conducted at the risk of another human being but as application of an already sufficiently tested theory. 
matter unknown may be so unknown to a party or to the court, and it may be unknown because it is unknowable; or merely because at a given period of time or at a particular place, the bases of knowledge are inaccessible or not readily accessible. In dealing with the unknown, the law is in a more favorable position than any other field of thought. It may, by the use of its own specific methods, completely disregard the fact that an element is unknown and treat it as known. By the same token, it may give it greater or lesser recognition. It may, thereby, consider the greater or lesser degree of accessibility of knowledge. This potentiality of the law is at present used in a manner which works injustice, at least comparative injustice.

From a realistic, practical point of view, there is no essential difference between matters utterly unknowable and matters which are only inaccessible to knowledge at a given time or place. The law, however, unconsciously basing its reasoning on specific conceptions of natural philosophy, draws a distinction between them. It gives full recognition to the former, but frequently disregards the latter. It thus takes full notice of the fact that the contents of religious beliefs are inaccessible to courts, but completely refuses to take account of the fact that a person on the high seas could not possibly have acquired knowledge of a law then enacted, ${ }^{79}$ or that a person cannot possibly predict what judicial interpretation a statute may receive in the future. In many respects, it neglects the various degrees of accessibility of knowledge. Similarly, it disregards the sphere of the unknown and hence disputable in science. To be sure, in all these matters considerations other than those of general philosophy may be decisive. However, natural philosophy is being used, though in an inarticulate manner, in rationalizing the resulting rules of law. Were it used admittedly and openly, many errors in reasoning could be discovered and corrected. It is submitted that such use as may be made of that philosophy should be made consciously, deliberately and consistently. ${ }^{80}$

\footnotetext{
70 Rex v. Richard Bailey [1825] Russ. \& Ry. 1.

80 Jerome N. Frank, in an unpublished manuscript (cited with the author's permission) states: "You remember Molière's Jourdain who was surprised to learn that all his life he, like literary men, had been talking 'prose'. So it is with 'practical lawyers' who regard legal theory as a frivolous subject unworthy of their attention. In reality these 'practical lawyers' are legal philosophers, but their philosophies, their theories, are usually 'inarticulate'; and, therefore, they are more likely to do harm than their colleagues who are more conscious of their pbilosophies, their theories. For the self-delusion of the unconscious theorists 'makes it psychologically easier for them to mold 'practice' in accordance with their behefs and prejudices without feeling the weight of responsibility that burdens lawyers with greater consciousness of the issues at stake.' [citing CoHEN, A Preface to Logic (1944) 174, 181, 182; Friedmans, Legal Temory (1944) 250, 251]."
} 